\title{
Rationality and Institutions
}

\author{
Jan-Erik Lane \\ University of Geneva, Geneva, Switzerland \\ Email: janeklane@gmail.com
}

How to cite this paper: Lane, J.-E. (2021). Rationality and Institutions. Open Journal of Philosophy, 11, 510-515.

https://doi.org/10.4236/ojpp.2021.114034

Received: September 15, 2021

Accepted: November 19, 2021

Published: November 22, 2021

Copyright $\odot 2021$ by author(s) and Scientific Research Publishing Inc. This work is licensed under the Creative Commons Attribution International License (CC BY 4.0).

http://creativecommons.org/licenses/by/4.0/

\begin{abstract}
It is now commonplace to renounce rational action in the social sciences. It is claimed that rationality as the maximization of self-interest is impossible as well as that it is unethical. Yet rational choice remains a most important paradigm for understanding human behaviour. D. Kahneman has contributed to the analysis of human action criticizing the two endpoints, namely perfect individual rationality on the one hand and group or collective decision making on the other hand. The first suffers from bias and the second from noise. Thus, there is somewhat of a contradiction here somewhere, as group rationality could not cancel out individual deficiencies.
\end{abstract}

\section{Keywords}

Intentionality, Causality, Bounded Rationality, Collective Rationality, Institutions

\section{Introduction}

Individual rationality is a model of personal choice behaviour, whoever he or she may be. It sets out from a perspective on life as a decision between action or no action, i.e. Kierkegaard's rejection of social determinism due to his model of life as Either-Or. We find this approach most clearly with Weber:

"Any conscious reflection on the most fundamental elements of meaningful human action is from the beginning tied to the categories 'ends' and 'means' (Weber, 2014: 102)."

One arrives at the model of rational choice or the neoclassical model by inserting heavy restrictions upon the ends and the means taking causation into account, allowing for the calculation of the maximum best choice (Neumann \& Morgenstern, 1944).

\section{Micro or Group Rationality}

A person makes individual choices or he or she participates in a group with oth- 
er people. The group could be small like 2 or 3 persons or large more like in an organization. Since organizations can be huge or even of ocean size, we concentrate upon top-level decision making like a government with several choice participants.

Now, the dominant theory claims that full rationality is impossible. This theory in modal form is supported in various branches of the social sciences. Only economics hesitates, defending full rationality as a convenient theoretical premise (Simon, 2013).

\section{Bias or Noise}

It may be remarked that Kahneman contributed much to the widespread rejection of:

S1. Full rationality in action is possible.

A number of empirical inquiries supported the rejection of $\mathrm{S} 1$ :

Policymaking (Allison, 2001); Public administration (Lindblom, 1959); Policy implementation (Pressman \& Wildavsky, 1984; Hjern \& Porter, 1981); Budgeting (Wildavsky, 1964).

The key theoretical framework of bounded rationality was handed down by Simon. Denying maximizing behaviour, he explained the failure of S1 with cognitive limitations and organizational complexity. A few scholars went a step further resigning rationality to chaos and organization failures, hidden by storytelling (Olsen \& Brunsson, 1998).

\section{Collective Rationality}

The concept of rationality may be given a purely macro interpretation as social equilibrium. In standard economic theory, the assumption of full rationality leads to optimal social equilibrium - first best solutions to problems of resource allocation-a most powerful theorem of combined individual and collective rationality (Bergson, 1966).

How about bounded rationality theory? What about collective rationality there? Simon argued that individuals satisfied but never maximized and those satisfying outcomes were just good enough! Simon never quantified satisfying.

Interestingly, Hayek launched a theory based upon bounded rationality leading up to his book Road to Serfdom in 1944 (Hayek, 1944). If people decided under bounded rationality, then large scale public budgeting and consequential planning were bound to fail. Men's cognitive limitations excluded a planned economy as well as a welfare state.

Market calculations were the best one could hope for, because the market fulfills another kind of rationality, namely a spontaneous order. A spontaneous order consists of a set of rules that people follow often unintentionally and sometimes unrecognizable.

A spontaneous order comprises rules, norms and principles for the coordination of human efforts, social coordination to mutual advantage. The spontane- 
ous order of global academic community automatically polices research and evidence to promote the growth of knowledge. Spontaneous orders emerge slowly and cannot be constructed. Individual rationality and collective rationality have no link (Hayek, 2014).

\section{Hayek and Popper}

Popper (1994) suggested that society could be improved by policies-piecemeal social engineering. Popper had no model of collective rationality except his rejection of totalitarian models. Piecemeal social engineering allows for welfare state spending and taxation like the slow construction of the Swedish welfare state with its comprehensive health and social care system. The Swedish model was not the road to serfdom.

\section{Collective Rationality and Institutions}

When arguing for $\mathrm{S} 1$, one adds that social order is guaranteed not by rationality but by institutions. But where do they come from? Why drive on the Right side? Because I maximize my utility. No, say institutionalists, due to the logic of appropriateness towards a traffic.

In his later publications, Hayek suggested a different foundation for his spontaneous order in an awkward theory of law. He separates sharply between legislation by a legislature on the one hand, and customs and case law principles on the other hand. Hayek suggests that only customary law is really law, whereas legislation stumbles on the fallacy of S1. Law making in Parliament fails under deficient individual rationality and is not conducive to collective rationality. Public law is worse than private law in protecting individual freedom. Too much public law leads to serfdom.

There is no support in jurisprudence for Hayek's political theory in his later books. On the contrary, legislation may improve society.

According to Hayek, S1 is false. Peoples' cognitive limitations prevent full rationality. Thus:

S2. All decision making is incompletely or imperfectly rational (March \& $\mathrm{Ol}$ sen, 1976).

This entails what? One may wish to distinguish S2 from the much stronger S3: All decision making is irrational.

\section{Micro Rationality}

Should one accept S2? If one adheres to S1, then maybe one would instead suggest:

S4. Decision making must constantly be updated.

It appears that bounded rationality is a static concept. When a decision has left out alternatives, why not go ahead and check them? When March's standard operating procedures result in lackluster performance, updating may reveal better prospects. Updating seems to solve the difficulties with S1 and S2. Can 
March's organization be innovative?

The sudden Afghanistan withdrawal by all foreign forces seems like a fully rational decision, although shockingly sad. The abandonment of the Afghans has revealed a set of policies carrying huge costs-corruption? There seems to be a bias for quick results coming in as well as going out.

\section{Bias and Noise}

Khaneman (Khaneman \& Twersky, 2000; Khaneman et al., 2021) points out two reasons for rejecting S1, namely bias with the individual actor and noise in the transfer of judgement by individuals. A typical example of noise is the variability in assessments of the same students, patients or merits. The difference between bias and noise is not crystal clear, noise may result from assessments with contradictory bias.

Noise has implications also for collective rationality. Too much variation hinders the evolution of spontaneous order.

\section{Means-End Framework}

The means-end framework is the paradigm for rationality in human action. When individuals pursue the wrong ends or employ the incorrect means, failure is bound to occur. Mistakes abound in human history and goals must be realistic

A goal is an idea in the mind about a change that an actor wishes to see done. If the change can be effectuated with some probability, it is realistic.

To be at all realistically relevant, the goal must be non-religious. Worldly goals can be achievable, but it depends upon the situation.

Thus, it has been much debated whether Hitler could defeat Stalin in 1941. There was noise as some in the Wehrmacht believed in a quick victory, whereas others (Paulus) advised against such a big operation. However, to Hitler, the war in the East had fanatical trust in his mission to eradicate "Jewish" Bolshevism.

The goal function may be simple or complex. Why invade Afghanistan? The primary goal was to get Ben Laden but the secondary was to fight the Taliban's, and enhance democratization. When Ben Laden was killed in Pakistan, the goal for the Afghan mission would be nation building, given that the Taliban's come from the largest ethnic group, i.e. the Pashtuns with some 40 percent of the population. Yet, the Afghan government was dominated by Tadjik's.

The Tadjiks constitute about 30 percent of the population. Talibans are a religious group, inspired by Islam in an Indian version. Not all Pashtuns are Talibans or vice versa.

A Taliban is a student from the Deobandi school of Islam, whose teachings emerge from the Sepoy uprising against British rule in greater India. Indian Moslems added a sixth duty-Jihad against infidels, and indiscriminate violence against the unbelievers took centre stage. Some students with Deobandi formed terror groups, which moderate Muslims did not endorse. On the contrary, Muslim governments have tried to restrain them. 
During the 20 century, the Deobandi theory was developed by scholars like Maududi, Qutb and AZ-Zawahiri. Terror attacks could be launched even against Moslems. With the war in Iraq and Syria more terror groups became active. Finally, Afghanistan had long experiments of Deobandi Islam due to the occupations and closeness to Pakistan.

\section{Improve Rationality by Nudging}

If one believes in S2, then one would still be interested in improving rationality somehow whereas S3 denies this possibility. (Thaler \& Sunstein, 2021) present nudging as a tool for rationality, i.e. a person is informed or directed to a better alternative. One could mention the death warnings on cigarette packs. Consumer sovereignty is a foundation for markets-how is it related to nudging? If government engages in nudging, then it collides with libertarianism.

In a dynamic perspective on rationality upgrading as well as nudging would be useful. People and organizations act under a rationality assumption or efficiency norm. They would be interested in finding new alternatives of action as well as new ways to estimate risk, even when it comes to protect vested interests. Perhaps much updating and nudging lead to the vindication of S1? The opposite to nudge is sludge but this distinction needs ethical confirmation.

\section{Heuristics of Rationality}

Even if bounded rationality is true of much human behaviour, it is difficult to deny S1, especially its usefulness in finding out why something went wrong: the many mistakes in human life. Sometimes people engage in long-term activity on the basis of intentions and causality beliefs. Let us call this "means-end chains".

Suppose we have two groups of persons: environmentalists and cornucopians. They have different values, i.e. means-end chains. Thus, we have:

E) Reducing $\mathrm{CO}_{2}$ emissions is a means to the goal of climate stability, whereas the conucopian would claim that:

C1) global warning is not real and thus $\mathrm{CO}_{2}$ reduction is not a policy means.

For the environmentalist, there is a means-end relationship but not for the cornucopian. A cornucopian like Bjorn Lomborg would likely reject the meansend relationship as well as the primacy of global warming. The crucial argument of the cornucopian is that:

$\mathrm{C} 2$ ) there is no causal connection between $\mathrm{CO}_{2} \mathrm{~s}$ and global warming.

Thus, the policy difference is different probability assessments about the link between emissions and temperature rise. Means-end relations involve values and beliefs about causation but they may be wrong leading to mistakes.

In warfare and policymaking one often finds actors with means-end relations that drive them to commit mistakes. Optimism turns out to be sanguine. People may believe in means-end relationships that lack any foundation in causality like, e.g, redemption in world religion. To quote Muhammad Atta checking in on 0/22: "tomorrow Paradise". 


\section{Conclusion}

The concept of human rationality has been over-criticized. It cannot be bypassed as in postmodernism. It functions like natural selection in the animal world. It is illuminating in the understanding of failures and mistakes, e.g. bias in individual decisions and noise in group decisions. Perhaps imperfect or incomplete rationality is as far as we can come, but the concept of rationality is still very useful for disclosing mistakes.

The concept of rationality is best seen as an ideal type with which to analyze actual behaviour. Formally, one may use expected value maximization with game theory or in ordinary parlance: Weber's action frame of reference. Besides intentionality, there must be a causal connection between the means actually employed and the actual realization of the end.

\section{Conflicts of Interest}

The author declares no conflicts of interest regarding the publication of this paper.

\section{References}

Allison, G. (2001). Essence of Decision. Pearson.

Bergson, A. (1966). Essays in Normative Economics. Harvard University Press.

Hayek, F. A. (1944). The Road to Serfdom. Routledge.

Hayek, F. A. (2014). Law, Legislation and Liberty. Vol. 3, Routledge.

Hjern, B., \& Porter, D. (1981). Implementation Structures: A New Unit of Administrative Analysis. Organization Studies, 2, 211-227.

https://doi.org/10.1177/017084068100200301

Khaneman, D., \& Twersky, A. (2000). Choices, Values and Frames. Cambridge University Press.

Khaneman, D., Sibony, O., \& Sunstein, C. (2021). Noise. Harpercollins.

Lindblom, C. (1959). The Science of "Muddling Through". Public Administration Review, 19, 79-88. https://doi.org/10.2307/973677

Neumann, J., \& Morgenstern, O. (1944). Theory of Games and Economic Behaviour. Princeton University Press.

March, J., \& Olsen, J. P. (1976). Ambiguity and Choice in Organisations. Universitetsforlaget.

Olsen, J. P., \& Brunsson, N. (eds.) (1998). Organising Organisations. Fagforbundet.

Popper, K. (1994). The Poverty of Historicism. Routledge.

Pressman, J. L., \& Wildavsky, A. (1984). Implementation. University of California Press.

Simon, H. (2013). Administrative Behaviour. Free Press.

Thaler, R., \& Sunstein, C. (2021). Nudge. Penguin.

Weber, M. (2014). Collective Papers in the Philosophy of Social Sciences. Routledge.

Wildavsky, A. (1964) The Politics of the Budgetary Process. Little, Brown and Company. 